\title{
Expression of 9G4 idiotope on autoantibodies to citrullinated peptides in patients with early inflammatory arthritis and established rheumatoid arthritis
}

\author{
Rita A Moura ${ }^{1 *}$, Inmaculada de la Torre ${ }^{2}$, Maria J Leandro ${ }^{3}$, Jonathan CW Edwards ${ }^{3}$, João E Fonseca ${ }^{1,4}$, \\ Geraldine Cambridge ${ }^{3}$
}

From 7th European Workshop on Immune-Mediated Inflammatory Diseases

Noordwijk aan Zee, the Netherlands. 28-30 November 2012

\section{Introduction}

The expression of $\mathrm{VH} 4$ gene family during immunoglobulin heavy chain synthesis has been detected in autoimmune diseases. In particular, the rat monoclonal antibody 9G4 detects VH4-34-encoded immunoglobulins and B cells expressing these antibodies as surface receptor (autoreactive $9 \mathrm{G} 4+\mathrm{B}$ cells).

\section{Aim}

To determine whether autoantibodies commonly associated with rheumatoid arthritis (RA) express 9G4 idiotope (9G4-Id).

\section{Patients and methods}

Serum from 27 patients with established RA and 46 polyarthritis patients ( $<6$ weeks duration) of whom $23 / 46$ were subsequently diagnosed with RA (Early RA, ERA) and 23/46 with other arthritis (Early Non-RA, ENRA) was studied. 9G4-Id detection on anti-CCP, anti-tetanus toxoid (TT), Pneumococcal capsular polysaccharide (PCP) antibodies and total serum IgG and IgM was measured by ELISA.

\section{Results}

23/27 patients with established RA had anti-CCP antibodies, 8 of whom had 9G4+ anti-CCP. All were positive for both IgM and IgG anti-CCP. 9G4-Id detection levels correlated more closely with IgM than IgG-CCP. In ERA

${ }^{1}$ Rheumatology Research Unit, Instituto de Medicina Molecular, Lisbon, Portugal

Full list of author information is available at the end of the article group, 15/23 patients had anti-CCP and 4/23 had 9G4+ anti-CCP. All 4 patients had both IgM and IgG anti-CCP. In ENRA, only one patient had 9G4+ IgM anti-CCP, albeit at low titer. 9G4-Id was not detected on TT or PCP antibodies.

\section{Conclusion}

We describe for the first time the expression of VH4-34 heavy chain gene by autoantibodies to citrullinated peptides early after RA onset. In established RA, the expression of VH4-34 gene by anti-CCP antibodies is positively correlated with their titer, particularly with IgM-CCP. Therefore, we suggest that the expansion of CCP-specific $B$ cell clones may be due to robust expansion of unswitched B cell clones, possibly including those in the splenic marginal zone or their analogous.

\section{Author details}

'Rheumatology Research Unit, Instituto de Medicina Molecular, Lisbon, Portugal. ${ }^{2}$ Rheumatology Dept., Gregorio Marañón Hospital, Madrid, Spain. ${ }^{3}$ Centre for Rheumatology, Division of Medicine, University College London, London, UK. ${ }^{4}$ Rheumatology Dept., Centro Hospitalar de Lisboa Norte, EPE, Hospital de Santa Maria, Lisbon, Portugal.

Published: 28 November 2012

doi:10.1186/1479-5876-10-S3-P30

Cite this article as: Moura et al.: Expression of 9G4 idiotope on autoantibodies to citrullinated peptides in patients with early inflammatory arthritis and established rheumatoid arthritis. Journal of

Translational Medicine 2012 10(Suppl 3):P30.

\section{C)

(C) 2012 Moura et al; licensee BioMed Central Ltd. This is an Open Access article distributed under the terms of the Creative Commons Attribution License (http://creativecommons.org/licenses/by/2.0), which permits unrestricted use, distribution, and reproduction in any medium, provided the original work is properly cited. 